\title{
6 Work based learning in intercultural settings: a model in practice
}

\section{David Elvis Leeming ${ }^{1}$ and Maria Dolores Iglesias Mora ${ }^{2}$}

\section{Introduction}

As part of an MA in Intercultural Business Communication at the University of Central Lancashire, we offer a taught module with a work placement that exists within a multicultural context. As part of this process, students must work towards completing two practical assessments, a project presented in a report format and a reflective essay. Our aim is to raise the international employment profile of our students by undertaking a professional intercultural work placement that will enhance their skill set through a guided process, from job search, to a critical reflection, to a final report of the project.

By undertaking the module, the students enhance their reputation by developing the required skills to stand out in the global marketplace. This is achieved by acquiring a high level of employability/enterprise skills that they will be able to articulate in order for them to succeed (Dacre Pool \& Sewell, 2007).

The module is structured by delivering two hour-long seminars per week for one semester followed by a minimum of a two month placement (this can be flexible and be done over a longer period on a part-time basis). The assessments are completed during this time and handed in a month after the placements are concluded.

The content of the module focuses on Intercultural Communication in the workplace, as well as the ability to secure a placement for the module and transferable skills that can used after they graduate. This allows the search for

1. UCLan, Preston, United Kingdom; DELeeming1@uclan.ac.uk

2. The Open University, Milton Keynes, United Kingdom; m.d.iglesias-mora@open.ac.uk

How to cite this chapter: Leeming, D. E., \& Iglesias Mora, M. D. (2016). Work based learning in intercultural settings: a model in practice. In E. Corradini, K. Borthwick and A. Gallagher-Brett (Eds), Employability for languages: a handbook (pp. 43-46). Dublin: Research-publishing.net. http://dx.doi.org/10.14705/rpnet.2016.cbg2016.461 
a suitable placement to begin within the first month of study. These content sessions are presented alongside Enterprise presentations that allow students to examine the skills/attributes of being an entrepreneur and/or intrapreneur. These are bolstered by delivery by specialised teaching staff and guest speakers. The tutor also offers one to one sessions and a great deal of support that is often called upon.

Keywords: international placement, intercultural communication, employability, intercultural placement, reflexive learning, reflective practise, MA study, UCLan, MA intercultural business communication.

\section{What we did}

One of the key skills we are trying to build is responsibility. The students themselves must make sure they secure the placement. Of course, as mentioned above, they are guided and mentored throughout this process. In terms of the placement being intercultural, we stress the importance of working for a company that is primarily from a culture different from their own. This allows the student to immerse themselves in that country and culture. The seminars lay the groundwork for this but the experience will help them to flourish and really begin to understand the differences and similarities of their host culture (Schein, 2004). Hence, when they enter the fulltime workforce, they feel they can work within such an environment.

The placement terms are agreed by the student, the workplace supervisor, and the tutor. The key is for the student to complete a project that not only prepares them for the challenges of the 'intercultural world' ahead but is genuinely useful for the company. As an example of a placement, a British student worked in Malta on the international marketing strategy for a Maltese company as they entered new territories. By undertaking such practical work, the students often realise that theory can only take them so far. As another student noted, 
"I realised that intercultural competency is a skill that cannot be learned from a text book. Even after living and studying in China for lengths at a time before the internship, I was not as interculturally competent as I thought. This is a skill that I developed over time at Bosch" (Student A, 2015).

The students also keep a reflective journal. This is kept from day one of the module till the end of the placement. The nature of the module calls upon a very personal methodological approach to the process. Our intention has always been to ground the work within reflexive methodologies, which was formulated from the work of Alvesson and Sköldberg (2009).

In other words, the students' own professional experiences on the placement are essential. The journal contains evidence of the student's experiences, encounters, thoughts, and growth. The students are the clearest advocates of the results of a combined module that examines intercultural theory with intercultural real world practices. Student B, a 2015 graduate, undertook a digital marketing post in Malta with her project subsequently leading her into a full-time role. She stated,

"the work placement allowed me to take these insights into practice working in a different culture, developing skills, and subsequently securing a job in a very multicultural company. I now work in an office with colleagues from Italy, Malta, Costa Rica, Venezuela, Portugal, Canada, and Spain, so my intercultural education is bound to continue into the future. All in all, this experience has benefitted me greatly, and allowed me to learn a lot about work in general, different cultures, digital marketing, and my own professional development" (Student B, 2015).

What has been fascinating is observing the networks that have built up since the inception of the module. This has meant that past students who undertook placements have now given talks about their experiences and even employed current students. This network will continue to expand across the globe with new and varied uses. 


\section{Discussion of outcomes and conclusion}

What we have learnt from this process is that we as a university need to make sure that we have a greater level of support for students who wish to embark on careers outside the UK. We hope this module will continue to go from strength to strength. Mainly, we hope to build our international networks so that many future opportunities will arise in permanent work, placements, shadowing, and research; in fact, the possibilities are endless. We end with comments made by one of our successful students; "this experience has given me a chance to think positively, motivate myself and weigh the advantages while achieving objectives. It has made me more confident" (Student C, 2015).

\section{References and links}

Alvesson, M., \& Sköldberg, K. (2009). Reflexive methodology: new vistas for qualitative research (2nd ed.). London: Sage Publications Ltd.

Dacre Pool, L., \& Sewell, P. (2007). The key to employability: developing a practical model of graduate employability. Education + Training, 49(4), 277-289. Retrieved from http:/ dx.doi.org/10.1108/00400910710754435

Reflective journals. (2015). By MA IBC, UCLan students. Retrieved from the MA IBC Repository.

Schein, E. (2004). Organizational culture and leadership (3rd ed.). San Francisco: Jossey-Bass. 


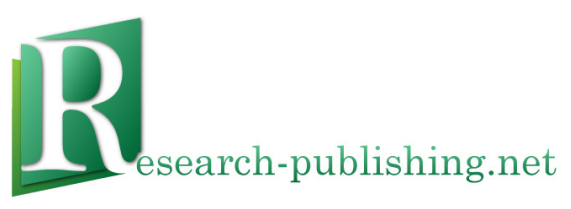

Published by Research-publishing.net, not-for-profit association Dublin, Ireland; Voillans, France, info@research-publishing.net

(C) 2016 by Erika Corradini, Kate Borthwick, and Angela Gallagher-Brett (collective work)

(C) 2016 by Authors (individual work)

Employability for languages: a handbook

Edited by Erika Corradini, Kate Borthwick, and Angela Gallagher-Brett

Rights: All articles in this collection are published under the Attribution-NonCommercial -NoDerivatives 4.0 International (CC BY-NC-ND 4.0) licence. Under this licence, the contents are freely available online as PDF files (http://dx.doi.org/10.14705/rpnet.2016.cbg2016.9781908416384) for anybody to read, download, copy, and redistribute provided that the author(s), editorial team, and publisher are properly cited. Commercial use and derivative works are, however, not permitted.

\section{(9) $\Theta \Theta \Theta$}

Disclaimer: Research-publishing.net does not take any responsibility for the content of the pages written by the authors of this book. The authors have recognised that the work described was not published before, or that it was not under consideration for publication elsewhere. While the information in this book are believed to be true and accurate on the date of its going to press, neither the editorial team, nor the publisher can accept any legal responsibility for any errors or omissions that may be made. The publisher makes no warranty, expressed or implied, with respect to the material contained herein. While Research-publishing.net is committed to publishing works of integrity, the words are the authors' alone.

Trademark notice: product or corporate names may be trademarks or registered trademarks, and are used only for identification and explanation without intent to infringe.

Copyrighted material: every effort has been made by the editorial team to trace copyright holders and to obtain their permission for the use of copyrighted material in this book. In the event of errors or omissions, please notify the publisher of any corrections that will need to be incorporated in future editions of this book.

Typeset by Research-publishing.net

Cover design and frog picture by (C) 2016 Raphaël Savina (raphael@savina.net)

Cover illustration by (C) 2016 Nicolas Fenix (www.nicolasfenix.com)

ISBN13: 978-1-908416-37-7 (Paperback - Print on demand, black and white)

Print on demand technology is a high-quality, innovative and ecological printing method; with which the book is never 'out of stock' or 'out of print'.

ISBN13: 978-1-908416-38-4 (Ebook, PDF, colour)

ISBN13: 978-1-908416-39-1 (Ebook, EPUB, colour)

Legal deposit, Ireland: The National Library of Ireland, The Library of Trinity College, The Library of the University of Limerick, The Library of Dublin City University, The Library of NUI Cork, The Library of NUI Maynooth, The Library of University College Dublin, The Library of NUI Galway.

Legal deposit, United Kingdom: The British Library.

British Library Cataloguing-in-Publication Data.

A cataloguing record for this book is available from the British Library.

Legal deposit, France: Bibliothèque Nationale de France - Dépôt légal: juin 2016. 